\title{
Territorial Development and Amazon Integration: A New Management Perspective on the Tri-border between Peru, Brazil and Bolivia
}

\author{
By Roberto Chiarella Quinhoes*
}

\begin{abstract}
Our study object is the tri-border Amazon territory that covers the Iñapari (Peru), Assis Brasil (Brazil) and Bolpebra (Bolivia) urban centers. In the future, the explosive and disordered urban growth will lead to a physical continuity between the three hamlets, due to a clear trend towards the formation of an international conurbation. The problems of the border towns will be exacerbated: environmental pollution, depletion of natural resources, delinquency, prostitution, drugs trafficking, smuggling, etc. This will hinder the territorial management of one of the worlds' richest areas in biodiversity, affecting the fragile environment and ecosystems of the Acre River basin. We intend to present a new development perspective of this area of study. In this regard, it is necessary to adopt a strategic approach that integrates territorial planning and management, crossing international boundaries. We are talking about the constitution of a single institutional structure for tri-border urban planning and management: an international city.
\end{abstract}

Keywords: Amazon, Borders, Urban/Territorial management.

\section{The Context}

The current international scenario related to territorial development is shaped by various processes that enable a new perspective on the Amazon and its projections of development in terms of planning and land management. On one hand, the process of climate change that is affecting the planet manifests itself in issues such as the melting of the poles, putting lives at risk in many coastal cities; the melting of glaciers which impacts the hydro-biological cycle and increases the risk of disasters and climate transformations, with higher incidence of drought in some areas and rainfall in others, affecting the lives of various species by destroying habitats and endangering endemic species and biodiversity in general. The main causes of the phenomenon of climate change are related to human activities, mainly industrial production and transport based on non-renewable fossil fuels, the expansion of global the process of urban growth, the destruction of forests, etc. As a result, the process threatens human life. In the final analysis, it comes to implementing new ideas and models of territorial management different from those of the past.

On the other hand, the process of globalization and fragmentation of national spaces leads to an appreciation of the local level, which is functional to the interests of the large international capital. In the South American context, the role of border areas is redefined and revalued as a result of the integration

\footnotetext{
* Associate Professor, Center for Research in Applied Geography, Pontifical Catholic University of Peru (PUCP), Peru.
} 
process of the continent. Simultaneously, the countries of the region privilege the political, administrative and economic decentralization, aiming to stimulate the generation of development processes in territorial areas other than the traditional national dynamic centers. In that sense, the role of urban centers is essential for international integration, national development and environmental conservation. In this evolution of situations the current South American integration process arises. In this regard, the proposal for the Integration of Infrastructure in South America (IIRSA 2014 ${ }^{1}$ ) aims to develop the region through a joint program to promote physical integration, implementing transport infrastructure, energy and telecommunications. Certainly, it came from an experience of planning and in the pursuit for logistics efficiency in Brazil. However, the proposal contains some imperfections that must be taken into consideration to improve the integration mechanisms. One of the main issues concerns the Indicative Territorial Planning Methodology, which does not have a truly territorial approach because it disdains in its conception the approach to the urban issue (Chiarella Quinhoes 2011).

From the previous context, the first initiatives seeking to organize the occupation and land use emerged, and in turn, questioning traditional approaches to borders, the same that ignore the role of networks in the construction of territory. In that sense, the perspective that privileges border integration, i.e. the use of the network approach as a tool for local development is constant in some border regions (Figure 1).

Figure 1. Localization of the Study Area

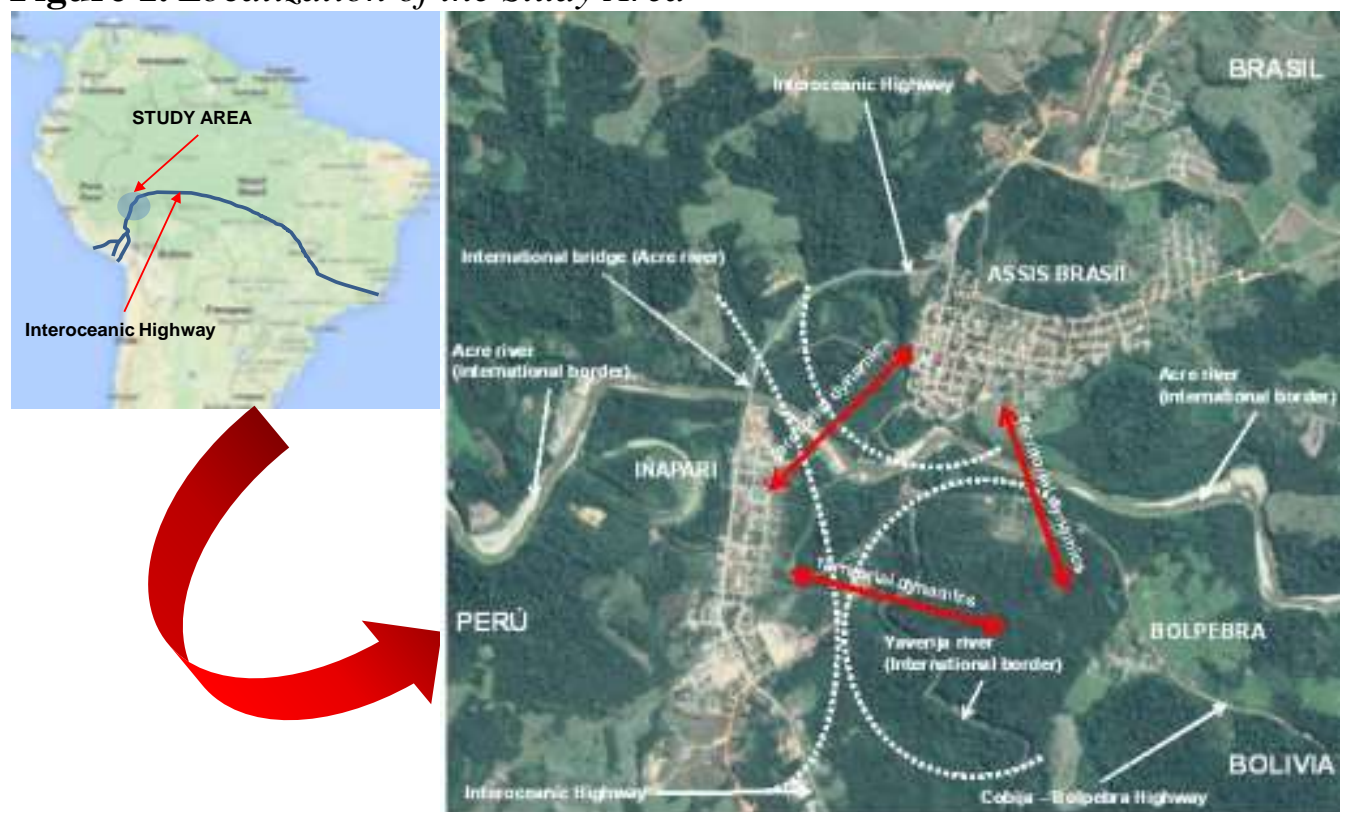

Source: Author's preparation, based on Google Earth.

\footnotetext{
${ }^{1}$ IIRSA. Retrieved from http://www.iirsa.org/.
} 


\section{Why Study the Tri-border?}

One of the main elements that compromise the proper management of the territory in the Upper Acre River is the disorderly growth of three tri-border towns Iñapari (Peru), Assis Brasil (Brazil) and Bolpebra (Bolivia). Three populations that are very close physically, historically and culturally and that are subjected to three different models of territorial planning and management, reflected in three different institutions, which offer different qualities of public services and employment opportunities, which directly impacts the quality of life of the population and its development prospects. These populations in the future will constitute a physical continuity: an international conurbation

We consider that there is a risk that the problems of urban border centers could worsen: environmental pollution, depletion of natural resources, crime, prostitution, drug trafficking, widespread, etc. This will obstruct even more, the efficiency in the management of one of the richest areas in biodiversity on the planet, affecting the fragile ecosystems and endemic populations of the Upper Acre River. In addition, the Interoceanic Highway-built under the IIRSA ${ }^{1}$ stimulates the emergence of various cross-border territorial dynamics that impact the territory.

In that sense, it is necessary to discuss the theoretical basis of planning: approaches, methodologies, methods, procedures and forms of management. To implement a strategic land management an appropriate administrative limit should be established. Identification, construction and densification of crossborder networks would be the platform to identify the likely limits of the new territory and give greater possibilities of development in the new global competition. Therefore, the development of the region should be planned from a holistic perspective of the territory that incorporates the three towns, with an integrated management of the public services, infrastructure and necessary equipment for that purpose.

On the previous context we identified that the central problem was the low levels of quality of life of the population and their insufficient growth expectations, which arise from a fragmented, inefficient and ineffective land use planning and management process that contributes to the destruction of the environment. Some questions, intended to clarify the system of relationships and socio-economic tri-border dynamics arise as well in order to identify patterns of land management: what are the factors that affect management? Which are the dynamics that make the competitive territorial integration possible? What is the appropriate management model to stimulate the generation of sustainable development processes?

The new scenario requires the identification of new management strategies, especially those related to public services. It is the creation of an

\footnotetext{
1 The work brought many benefits-reducing travel times and transportation costs, and enhancing cross-border trade. However, the studies were not conducted with the appropriate rigor which originated unwanted or negative effects expected. The cost of the project was initially estimated at $\$ 860$ million and by 2012 had reached US $\$ 2.400$ billion. Impact studies on territorial dynamics, migration and urban growth processes were not performed.
} 
"International City"-with characteristics of an intermediate city-which would allow a unified planning and land management approach. The perspective has the preservation of the environment beyond borders as the central axis. We must emphasize the fact that our object of study is based on: i) being a triborder area, ii) high biodiversity, iii) explosive urban growth, iv) future impacts on the environment and its resources and v) a model of urban and regional planning and fragmented management.

Consequently, our work is contained within the issue of territorial planning and management in the tri-Amazon border, and their relationship with the processes of integration for development. Its aim is the discussion of urban growth processes of the three cities, evident cross-border territorial dynamics, and its connection with the wider land management of the Amazon process. Its objective is also to bring a new understanding of territorial planning and management from the perspective of environmental conservation and protection of ecosystems, in order to establish guidelines and strategies that serve to develop a tri-border territorial management model that allows encouraging the raising of the quality of life and improving the prospects of development of the local populations (Chiarella Quinhoes 2014).

The methodology is aligned to the classic proposal of strategic planning, rescuing the competitive aspects of the territory and the establishment of tendential logic of scenarios. Our approach privileges aspects of environmental conservation, land management and employment generation. The implemented strategy is based on a comparative analysis of public policies, which are addressed through different scales of territorial analysis: South American, whose frame is IIRSA; national scales corresponding to each country; regional scales, considering the Amazon; local scales, corresponding to the municipalities in the tri-border and the territory over the politicaladministrative borders.

\section{Background on Integration}

After reviewing some of the most significant initiatives regarding the integration of border towns we came across that most of them arised from informal and spontaneous processes formed from family, historical, cultural, social and economic ties between different societies on both sides of the border limit. Also, we found processes whose proposals have emerged from a more formal and planned manner. In Europe, there are several examples, such as the integration process between the city of Luxembourg and the Swiss cities of Basel and Geneva, where the border-far from constituting an obstacle to cooperation-offers opportunities to strengthen the comparative advantages from strategies that articulate certain functions of the border using different logics. It notes that the border can be mobilized as an economic resource or a more symbolic level, as an object of recognition and affirmation of the international character of a city (Sohn 2010). Another illustrative example of integration is the one between the small Italian town of Gorizia and the 
Slovenian city of New Gorica. On December $21^{\text {st }}, 2007$ after the entry of Slovenia in the Schengen Agreement, the border controls between Gorizia and Nova Gorica ended and free movement between the two parts of the city for the first time was allowed in more than 60 years. However, we must add that the opening of the border with Slovenia hurt Gorizia's financially chances of development, because buying in Slovenia was cheaper when compared to the Italian city. It is also important to mention the case of the city of Tornio in Finland, which coexists with the Swedish town of Haparanda. Both cities have a common history as the twin cities and are planning to merge under the name EuroCity. They are currently building a new urban center in the border and they already share many municipal services and a golf course located along the border. The new center of the Ikea multinational corporation in Haparanda is labeled in Finnish and Swedish and the prices are listed in the currencies of the two countries.

In Minor Asia, we highlight the case of the city of Jerusalem, which is divided into two: the east side is Arab and the west side is Jewish. In 1947 the UN passed the Resolution $\mathrm{N}^{\circ} 181$ which established the partition of Palestine into a Jewish and an Arab state. The city of Jerusalem had the status of an international city-neither Jewish nor Arab-managed by the Trusteeship Council of the UN, which would appoint a governor for the city. However, the nonacceptance of the Arabs and the invasion of Israel, after its declaration as a State, prevented the implementation of that resolution. West Jerusalem is the commercial heart of the city, becoming the development center of the city. East Jerusalem is the center of the Palestinian settlement around the Old City. After falling under the Israeli control, a large number of Jewish neighborhoods were created. It should be noted that the city failed to integrate it all, it is a place physically, culturally and socially divided, where a lot of conflicts of religious origin prevail.

In North America, there is the case of the cities of Tijuana (Mexico) and San Diego (USA), where despite the restrictions caused by the difficulty of border crossings and the security policy of the USA, there is a trend towards economic integration. However, this still represents a challenge because half the population of Tijuana cannot cross the border and most of the population of San Diego does not want to cross, so that the interaction between the two populations is low. Also, there are no integrated markets that form a single space, and the prices, as well as the components that influence them are different in each city. So, Tijuana and San Diego constitute an urban continuum separated by an international border, which functions as two cities (Alegría 2009). In a final analysis, we can say that this is an international conurbation. In Central America there is an integration framework represented by the Central American Integration System (SICA), in which the Open Borders Project developed, focusing on the triple border areas, the Trifinio and the Gulf of Fonseca. The Trifinio region, located between Guatemala, Honduras and El Salvador, is an area in which the integrated and balanced development of the region is driven by the joint and coordinated by governments and actors (Conato 2009). 
In South America, there is the case of the cities of Chui (Brazil) and Chuy (Uruguay), which form an urban system that has a high permeability through the two nuclei, checkpoints and geographical barriers. They are formed by small settlements that live off commerce and services, especially during the summer when the region receives many tourists. The conurbation is small and the urban sprawl consists of houses reflecting the low income of the population intended to absorb the migrant rural population in both countries. The conurbation is almost like one society, so it is difficult to perceive them separately. Their level of symbiosis is really high, sharing a centrality, and patterns of social and spatial segregation in every way. It should be considered that in heterogeneous border areas and those where there is a spatial organization it is necessary to formulate a suitable plan for each situation, which seeks to reduce administrative burdens, facilitate communication, encourage exchanges and create conditions for private investment. In that sense, it is necessary to break the myth of rigid boundaries, give other functions to the borders and seek peace in daily living (Valero 1998).

There are various studies, plans and development proposals for our area of research. However, most studies do not consider a comprehensive perspective of the three population centers, most of them are made from a fragmented vision of the territory, ignoring the set of dynamics that characterize this border. Other works focus on the relations between two countries, starting from a particular nationality centered vision. We believe it is necessary to develop a comprehensive perspective of territorial development that includes Iñapari, Assis Brasil and Bolpebra as part of the same territory and the same urban management. The important role played in the region by the MAP initiative (Madre de Dios - Acre - Pando) should be noted. In 1999, due to the transformations caused by global environmental change, representatives from universities, research centers and development agencies met at the Federal University of Acre, Rio Branco, where discussed about more effective articulation of regional institutions forms. This meeting resulted in recommendations that were used to develop the "Declaration of Rio Branco on global changes" in 2000, and it was here that it was possible to initiate a process of articulation and organization of tri-border actors and operators in which the State was absent. The short history of trinational coordination in this space reveals potentials that are worth attention by the States involved, as local institutions, supported by NGOs, decided to jointly handle the problems and opportunities their trilateral dimension. We emphasize the presence of the Madre De Dios Consortium, created with the support of USAID, as part of the conservation initiative in the Andean Amazon (ICAA). The CMDD seeks to strengthen environmental management capabilities of local actors in the region, through sensitization activities targeting citizens, adults, government employees, authorities and leaders, as well as children, academics and researchers. 


\section{What Happens in the Tri-Border?}

\section{A Brief History}

The history of the tri-border territory presents the convergence of several territorial dynamics-economic, social, political, etc.-along with the time, those were stimulated by processes that occurred in various scales of analysis that range from the international framework to the local level. These processes generate different types of migration flows to and from the region, which in some cases sets multiethnic populations that occupied the space as a reflection of the different forms of exploitation of natural resources. In this sense, territorial occupation has impacted the environment in a differentiated way. A clear example of this is provided by the use of a raw material that have been discovered and used since a long time by indigenous peoples (the latex from rubber trees). In the late nineteenth century, the deepening and expansion of the industrial revolution and the formation of monopoly capitalism allied to new methods of treatment of the latex-opened the international market, prompting countries to promote the occupation of their Amazonian territories. They cherished the source of the resource and generated the process of occupation and border definition.

The two forms of extraction of latex induced different forms of settlement. The caucho caucho present in the valley of the Madre de Dios River-Peru-led a nomadic population, scorched earth and a continuous penetration. The seringa, mainly present in the basin of the Acre river-on Brazil and Bolivia led to a permanent occupation, the formation of population centers and the setting in the forest. Both processes were driven by States through reconnaissance expeditions, land grants and military presence. It is necessary to study the spatial and social consequences of the colonization of the people in the area as well as the transformation of the Indian borders into others imposed by the state and the survival strategies adopted by the people who persisted expropriated of their lifestyles, incorporated into the latex extraction process, economic activity that reorganized the space in the framework of social relations between Indians and new immigrants, generating networks of dependence and domination. Genocide strengthened the destruction by the extractive expansion; the survivors were subjected to exploitation by a minority of new owners. Recently, agricultural expansion, gold mining and timber extraction shape a new landscape, with the increased presence of States in the area.

With the advance of colonization, indigenous people were isolated from their context of regional sociability, passing it all to mediation by the State and religious groups. The state created sociological cuts which incorporate and are assimilated by Indians. Today, they are a permanent and ambiguous presence and they have started revalorizing their specific identities. In this regard, the border and the legal differences between countries is an important resource that is exploited today. 
The history of contact of the Indians with non-Indians is told by them in different historical times. Before the arrival of the Brazilian Northeast people, the remote time is called "ancient". The "time of the raids" began with the extraction of rubber trees. After that time starts the "time of captivity," it was when the Indians worked in the rubber plantations, as extractors, farmers, etc. Then came the "time of rights" linked to the discovery of indigenous rights, and the "time of cultural revival" (together with the previous), the rescue of traditions. The reaffirmation of identity occurs through the claim of its territory and the recognition of their culture that allows them a place in the world. We must study the indigenous peoples, for whom the political border represents multiple belongings and analyzes the relationships between political and social borders from the practices and representations of its inhabitants, forged by identity references, with which they define and are defined in classifications that reproduced and deny limits and boundaries between groups (Manchineri and Morais 2011, Arruda 2010, Simoes 2009).

In the tri-border there are commercial ties between the Manchineri and the other natives of the region since the time of the Amazonian colonization. These groups inhabited the region and had contacts with Andean societies. The formation of the border caused serious problems for Manchineri, Piro/Yine and Jaminawa groups, and other people who disappeared because of the rubber expansion. The indigenous people are sometimes on either side of the border and are bilingual because that movement requires speaking a language that is different form their mother tongue (Arruda 2010).

\section{General Overview}

We must analyze the various forms of territorialization of the same space by different actors, who live with the differences established by the political and administrative border. This is a reality characterized by constant changes that now is living a fact that is part of an overall process that impacts the relationships between populations: the Interoceanic Highway, which adds value to a space considered peripheral. In this sense, two hypotheses related to the articulation of the tri-border system arise: a) the logical state does not match the logic of the population, so that the official borders are faced with other cultural boundaries generated from the interactions between the populations, which reaffirm or deny the borders according to their interests and b) the changes generated by the Interoceanic Highway and population migration affect the relationship between society-nature.

Differentiated occupation of the territory has been driven by different rhythims of growth and development of its various regions. In Brazil, the colonization projects financed by the state in the 1970's supported a development based on the expansion of the agricultural frontier and the modernization of agriculture. This conservative modernization allied big capital to large estates, with the intention of developing the agricultural activity and fill the empty spaces. The idea of the demographic vacuum and the belief 
that it was a potential agricultural area were the basis of the policy that guided the development model implemented in Brazil, Peru and Bolivia.

In the context of globalization we see that one of its main effects are manifested in the evolution of the concept of border to levels at which processes of "des frontierization" configure extended economically integrated areas, surpassing border limits. In such areas there is the recognition of historical, anthropological and sociological factors underlying feelings of identity and belonging that were unknown to the political and administrative limits imposed by the nation-state. The combination of processes of des frontierization with feelings of identity and belonging, lead to the establishment of regional border areas, cross-border scenes of territorial dynamics that directly involve three countries, putting at risk, in practice, the validity of concepts that support the nation-state, such as those relating to state, territory and sovereignty with which it was intended to legitimize the separation effect of the boundary.

There is a socio-economic system that integrates heterogeneous populations, and which emergs from the existence of cultural boundaries and cultures of borders. Local references of identity are central to the daily interaction that allows people to differentiate between "Bolivian", "Peruvian" and "Brazilian" and "Bolivian border", "Peruvian border" and "Brazilian border". In this sense it is found that the state images failed diluting local references. The state of Acre (Brazil) is a clear example of the processes produced within the national state. The extraction process of latex attracted thousands of people, mainly northeastern people who were fleeing from the implacable desertification to the region, which influenced the subsequent change of borders. Colonization was accompanied by population changes, the rubber tappers expelled the indigenous, and in turn, the first ones were expelled by ranchers and settlers. Border policy changed from a socio-economic occupation of the territory.

In the department of Madre de Dios (Peru) the colonization of the forest was, in part, similar to Acre. However, colonization responded to spontaneous migration movements and others targeted with the intention of expanding the agricultural frontier, mainly from the Andean population, whose relationship with the land is different from the Amazon inhabitants. This, subsequently, was also stimulated by government policies of the 70s'. Today the region is invaded by thousands of illegal miners and loggers.

In the department of Pando (Bolivia) the process of occupation was similar to Acre and Madre de Dios, in terms of the extraction of latex. However, the election (and recent re-election) of Evo Morales not only changed the relations with neighboring countries, but also the internal balance of power between central government and local governments, with a more expressive impact on territorial organization on border areas. The output pressure of Brazilian immigrants and land owners, from a stretch of $50 \mathrm{~km}$ considered from the border with Brazil, was accompanied by incentives for colonization given to Bolivians. Investment in transportation infrastructure is seeking to reverse the ancestral isolation of northern Bolivia in relation to the political center of the 
country. In this regard, the government is promoting the occupation of the border region with the intention of strengthening the presence of the national state.

The form of appropriation and occupation of the territory is made through a process that we can call "fronts". The occupation in all three countriesinfluenced by the occupation of Acre-is performed by three types of fronts: a) the extraction front, mainly rubber tree, chestnut, wood and gold, b) the indigenous front, when the Indians were expelled from their land and came to occupy new areas and c) the agricultural front, which in many cases is even encouraged by state policies (Machado et al. 2013).

\section{Urban Characteristics}

Iñapari and Assis Brasil generate a space of relationship and socioeconomic complementation that constitutes an international urban system, with similar urban characteristics, not only in form but also in terms of their activities, socio-cultural similarities and similar patterns of land occupation. Physically both cities are divided by the Acre River that although is a natural barrier, has not been a limitation to affirm economic and cultural relations throughout time. Both cities workpartially as if they were a single population. Affiliation ties and economic relations between the two locations are common; this has allowed creating strong ties of friendship and shared development, including Bolpebra, to a lesser extent.

The Iñapari district has experienced in recent years, an accelerated process of urbanization, which has changed the composition of the population occupation of its territory tending it to be located in the urban core. The physical-spatial organization has been generated from the original nucleus characterized by the central rectangular blocks where the Plaza de Armas and its main institutions are located in a Spanish style. The main characteristic of the city is predominantly residential and the service activity primes above the other land uses. We can notice that the deficiencies in the system of garbage collection and disposal of solid waste, generates an environmental problem that is reflected in the existing of a garbage dump found next to sources of drinking water catchment. There is no system of wastewater treatment and the public drainage system is deficient because the pipes in its final section discharge the wastewater without any prior treatment, contaminating nearby rivers, also networks of drains on its way are fractured. In Iñapari economic activities are of small scale, mainly related to forestry and tourism services. The production potential is based on industry and is handmade to take advantage from the forest resources and services related to tourism. The activities which mostly employ labor correspond to the retail, restaurants and public services, either as employees or self-employed workers. It should be noted that commercial activity was more dependent to Assis Brasil before the construction of the Interoceanic Highway. But the road does not leave resources for Iñapari local government since the toll is for the concessionaire. On the other hand, several State social programs do not reach the city and the special fund for the 
municipalities' border, which established the Organic Law of Municipalities (Ley Orgánica de Municipalidades $2003^{1}$ ), was never implemented, so the local government resources are scarce. However the Peruvian side of this road is in good condition due to the concession model that requires the concessionaire to perform periodic maintenance of the road. There is significant commercial activity with Assis Brasil, which has been modified since the construction of the Interoceanic Highway. Before this fact Iñapari was heavily dependent from Assis products. Now, its closer links with the departmental capital Puerto Maldonado has changed the flow of supply and flow costs. Note that when a great flood prevented connecting Rio Branco (Acre state capital), Brazilians stocked for several months of the Peruvian products.

The town of Assis Brasil, is located southeast of the state of Acre, it is classified as an urban rural settlement in a process of urbanization and consolidation as a center of services, with a population of over 6,000 inhabitants $^{2}$. The conformation is defined by an orthogonal layout in typical checkerboard form and its land use characteristics are similar as those from Iñapari, but with a greater population density, level of urban consolidation, equipment and utilities. The livestock plays a dominant character and Assis provides education and health services-from March 2013 also to Bolpebra and Iñapari. The city has developed its commercial and service activities more. The commerce of goods, industrial foodstuffs, hygiene articles, etc. is marketed in Assis and it supplies mainly the population of Bolpebra. It should be noted that a significant part of its territory is affected by exploitation of livestock and agricultural farm, experiencing a rapid expansion process, and that the State itself technologically and financially supports the development of this sector. The role that is currently played in the region by the Brazilian Service of Support for Micro and Small Enterprises is also important (Sebrae). This scenario is not seen with the same intensity in the district of Inapari-and much less in Bolpebra-not only because Iñapari retains a part of its territory in its natural state, becoming its main potential and comparative advantage, but mainly because the state is far from promoting the development of the territory. Trade also plays a double role: mediating bilateral trade flows and exchanges of exportable offers and complementing and developing local catering and population exchanges. In the basin, conflicts between adjacent areas with different uses are verified, in addition of the impact of urban growth on the environment.

The main economic activity on Bolpebra is the subsistence agriculture (including breeding poultry), followed by the harvesting of natural resources and livestock. Until a few years ago there was a business relationship with Iñapari (even bread was led from Bolpebra), but now this link has been weakened with Iñapari and reinforced with Assis Brasil where the population acquires various products and promenades on the weekends. However, scheduled public investment projects seek greater rapprochement with Iñapari,

\footnotetext{
${ }^{1}$ Ley Orgánica De Municipalidades - 27972. Organic Law of Municipalities. Retrieved from http://goo.gl/9rN9tq.

${ }^{2}$ Township information obtained in fieldwork 2014.
} 
in addition to investments in transport infrastructure aimed at breaking the historical isolation of the region. In this regard, there are completing the paving of the road between Bolpebra with the capital of the departament of Pando, Cobija. There are virtually no public services in Bolpebra; even the municipal headquarters is located in Cobija. In the town there is a vision of territorial development from tourism and trade.

The public authority intends to execute a project to connect Bolpebra with Iñapari through a pedestrian bridge over the Yaverija River, and to build a tourist lodge and a lookout and it counts with the necessary financial resources. It should be added that recently (2014) the government of President Evo Morales has allocated substantial resources to the region, which has allowed the construction of about 40 houses and a school for basic education. The homes also have electricity due to installing solar panels. The drainage system considers the treatment of the drains by passing them through four filtration pools and the subsequent channeling to a general network (under construction) which derives a special wastewater treatment facility (in the future). There is no garbage collection so people burn it at the door of their house. In addition, the government has built a covered sports center for the practice of physical activities and events of the population. Also, the opening of the foregoing was done with the presence of the president. It is for these reasons that we have noticed a positive perception of the president in the area.

\section{Population Growth}

Since the year 2000 approximately, population growth has intensified in the tri-border introducing a very worrying future scenario. Iñapari district experienced in recent years an accelerated process of urbanization that changed the occupational composition of the population seeking to locate in the town center, with an average annual growth rate of $7.5 \%$, which would mean more than 1,200 urban populations (2014). It is estimated that there are about 1,000 people of floating population, who work, study and trade in Iñapari, residing in Iberia and Assis Brasil. It should be added that the people that works in the low mountain go down to the city in the weekends for rest and recreation.

The results of our fieldwork and the use of official sources as the Brazilian Institute of Geography and Stathistics (IBGE, Brazil) ${ }^{1}$, National Institute of Statistics and Information (INEI, Peru) ${ }^{2}$, National Institute of Statistics (INE, Bolivia $)^{3}$ and the information collected directly from local governments, allows us to project the population growth in the coming years (Table 1). In this sense, we can say that the tri-border total population in 2010 would increase from 8,862 to over 28,000 in 2040 .

\footnotetext{
${ }^{1}$ IBGE: Instituto Brasileiro de Geografia e Estatística. Retreived from http://goo.gl/bjDi.

${ }^{2}$ Instituto Nacional de Estadística e Informática-INEI: Retreived from http://www.inei.gob.pe/.

${ }^{3}$ Instituto Nacional de Estadística. Retrieved from http://www.ine.gob.bo/.
} 
Table 1. Evolution of the Population in the Trifrontera

\begin{tabular}{|c|r|r|r|r|r|r|r|r|}
\hline \multicolumn{7}{|c|}{ STATISTICS AND POPULATION PROJECTION } \\
\hline YEAR & \multicolumn{2}{|c|}{2005} & \multicolumn{2}{|c|}{2010} & \multicolumn{2}{|c|}{2015} & \multicolumn{2}{|c|}{2040} \\
\hline TERRITORY & TOTAL & URBAN & TOTAL & URBAN & TOTAL & URBAN & TOTAL & URBAN \\
\hline IÑAPARI & 1,252 & 791 & 1,408 & 888 & 1,577 & 1,262 & 6,768 & 5,414 \\
\hline ASSIS BRASIL & 5,063 & 3,544 & 6,075 & 3,703 & 6,804 & 5,103 & 18,138 & 13,604 \\
\hline BOLPEBRA & 1,316 & 140 & 1,379 & 180 & 1,950 & 250 & 4,083 & 600 \\
\hline TOTAL & 7,631 & 4,475 & 8,862 & 4,771 & 10,331 & 6,615 & 28,989 & 19,618 \\
\hline
\end{tabular}

Source: Institute of Geography and Statistics, Brazil (IBGE), National Institute of Statistics and Information, Peru (INEI) and National Institute of Statistics, Bolivia (INE). Prepeared by Author.

The data above shows us a very worrying outlook for the region and leads us to reflect on the need to increase the coverage and quality of public services, equipment and infrastructure to adequately meet the demands of the tri-border population within the context of environmental degradation impacts due to the explosive urban spread and mismanagement. The migration processes of uncontrolled populations that are attracted by economic expectations alter the limited range of services that partially meet the social demands and the right level of employment, income and governance of the territory.

\section{A New Perspective over the Tri-Border}

In recent decades, geographers faced with the emergence of a new area of research: planning and management of sustainable development of the territory. We note that in the field of planning, some confusion still persists in the aspects of theory and practice, as some professional activity remains focused under a strong economicist and constructivist rationality, which covers concepts and criteria necessary to formulate a multidimensional vision of the fundamental development problems.

The evolution of geographic development thinking owes its genesis to the studies undertaken in the field of economics. However, we emphasize the importance of place and space as central elements of geographical differentiation, being that difference that makes a location competitive and attractivegiving conditions for the installation of the capital that will contribute to the generation of the territorial development processes (Chiarella Quinhoes 2005). We believe that geography contributes to the construction of a new theoretical framework so as through a global conception of the sets recovers the value of the place and space, not only in the description but in the further analysis of the contextual relationships that affects the territory (Chiarella Quinhoes 2010).

It is argued that planning is in crisis and that, consequently, the proposal of Land Management as an alternative to lead the development of the territory emerges. In this sense we should prepare for her funeral. However, what is in 
terminal trance is the way we do planning as a collective project of social engineering of enlightenment rationality, a situation that is typical of the wider crisis of modernity. The discussion should focus on the type, form or characteristics of planning. In the final analysis, we should be more consistent and talk about territorial management (Boisier 1996). The planning that considers only the physical limits of the city without analyzing their relationship with the territory is a useless reductionism and sterile exercise. We consider as a priority the construction of a vision concerning the territorial and urban development in the tri-border that can guide the actions of the planner and decision makers. In this sense, a privileged role to the geographer should be assigned, as a professional who works from a holistic perspective with the space categories: processes, structural elements, morphological and landscape construction aspects; rescue lived space; issues related to the scales, networks, and core flows; borders, etc.

We note that the conceptual division between town and country that is set to the theme of territorial planning persists, specifically in urban planning. The various published texts generally offer isolated studies that focus on rural areas or in urban space, thus ignoring the multiple relationships, connections and articulations between urban development and the development of the territory of which it is part. Some works are based on merely technical issues, thereby reducing the problem of planning to method studies, booklets, guides, etc. Others are limited to meager budgets that do not even cover the needs of planning itself, usually made from an economic perspective. Finally, other texts exposed abstract and complicated theories on urban planning, from a morphological, behavioral and perceptive view. So, at this time, arises a widely debated issue in recent times among planners, the relationship between processes and elements that structure urban space and those that do it in territory. The problem of the relationship between these processes has two different aspects. On one hand, the structure of both spaces is part of a unique process of global capitalist development and on the other hand, the consideration of the urban core is the key for territorial development. Both presuppose the development of scientific research in planning as something different from the plan.

The complexity of the requirements posed by territorial planning are substantially increased in recent decades, requiring new methods of planning different from traditional methods based on top-down planning or its opposite, from the bottom up. Planning is an integrated set of an increasingly complex unit, where different scales are related horizontally and feedback planning systems. The identification of processes and structural elements of urban space in a border town is enriched by the prospect of working with three cores. This justifies the reaffirmation of the importance of the methodology for development planning problem, it is not a purely morphological, economic, social or environmental order.

The low quality of life of the population in the tri-border is directly linked to the use of planning and management tools that are inadequate to the reality of the territory. This originates from the absence of a shared vision of 
development for the three studied locations, predominantly narrow visions anchored in the national State not take into consideration that we must analyze the territory from the perspective of a single Amazon territory, across national borders. This vision should guide the formulation of a single strategic plan for sustainable development of the territory. Consequently, we should identify integrated management mechanisms, with the aim of providing better services to citizens. For this management to be implemented efficiently and effectively it is necessary to reflect on the possibility of establishing a territorial tri-border system and identifying appropriate new administrative limits for it.

\section{The International City}

The spatial reorganization of capital in the context of globalization induces processes that alter location decisions and the productive matrix of urban conglomerates. Due to the condition of nodal points of networks of local, regional, national and international communications, cities provide the essential relationships for the operation of all levels of territorial planning. However, the geographical proximity between countries is not a sufficient reason for integration; for this to make sense is necessary for countries to share a common project of political-territorial organization and geopolitical projection, industrialization, economic integration and strategic policy in the international system. The issue goes beyond simply building an infrastructure to tap the complementarities of resources and comparative advantages of national economies in a regional free trade area and to create facilities to increase the regional flow of goods, resources, people and ideas.

For geography there is no unique right way to divide space because we can change the articulations according to our intentions and even the organization of the territory of the nations may be extended by studying their social networks along with evidence of economic structures. In addition, although urbanistic decisions, because they are administrative or government decisions are formulated in the territory from its administrative divisions, the phenomena behind these decisions are often explained in other levels of relationships that the city has with the territory and that exceed municipal boundaries (Claval 1979, Chiarella Quinhoes 2005). Thus, the territorial planning should be treated from an integral perspective, reducing the impacts of the urban dynamics in the territory.

The need to articulate the Amazon regional integration with local development, underlines the urgency of creating convergent areas that can promote development processeses, both institutionally and economically. Transboundary process may become the organizing element of the areas of socio-economic and institutional convergence, where different designed projects become functional and dependent variables of the reality of an international city. It should be noted, still, some of the current effects of having three distinct urban efforts in the region and that are linked to the provision of public services: the residents of the poorest countries tend to cross the border and to go to the more developed country's urban center seeking for jobs and to 
get benefit from better services. Sometimes, they prefer that their children are born in the most developed country so they can enjoy all the benefits of citizenship such as health and education, among others. All this impacts the demand for public resources to meet the needs of the more developed population. Ultimately, it impacts on the quality level and in the cost of the public service provided by the more developed country.

On the previous context, it is arised the idea that the most efficient way to manage the tri-border territory is through an integrated planning and urban management. This leads us to propose the creation of a city that includes the three urban centers and institutions which allows such planning and management. In this sense, this new perspective of the Amazonian territorial development-passing over national borders would be the most appropriate mechanism for urban management in terms of efficiency in the delivery of urban services for the citizen, and at lower costs impacts on the environment and its resources. This, ultimately, is related to a process of destruction of the old regulations structure and mindsets to create a new model of urban management in the Amazonian tri-border area (Chiarella Quinhoes 2014).

For the international city's creation purposes, urban centers should be prepared to meet the challenge of change processes, meet the new demands and development contexts. In that sense, it is necessary to identify new functions and processes of urban structure, imperious to host activities to ensure employment, income, adequate governance and services that are compatible with environmental conservation. Also, it should create an atmosphere of agreements and commitments, at different levels, allowing synergies, resources and tools to regulate and foresee the impact of the creation of an international city, avoiding indiscriminate manipulations of the new demands for services, income and employment, which endanger the capabilities of managing the development of the city. It should empower urban support, consistent with new features, new demands and expectations deriving from the process of integration and tri national exchange. We believe that development must be planned from the perspective of an international city, through integrated planning and management of urban services, infrastructure and necessary equipment for the assimilation, training and encouragement of the people on the long road of integration for the development of the Amazon.

\section{Final Reflections}

One of the main effects of globalization is the transformation of the concept of border to levels at which the process of des frontierization come to configure extended economic areas and economically integrated over the boundary lines. In these spaces the recognition of historical, anthropological and sociological factors underlying feelings of identity and belonging that were unknown to the political and administrative limits imposed by nation-states occurs. The combination of processes of des frontierization with feelings of identity and belonging, leads to the configuration of regional border areas, 
stages of economic and social dynamics that directly involve three countries calling into question, in practice, the validity of concepts that support the nation-state, such as those relating to State, territory and sovereignty which were intended to legitimize the separation of the boundary effect.

The core strategies that should guide the tri-border territorial management to sustainably environmental exploitation should focus their impetus in sustainable economic activities; strengthening food security strategies; environmental protection related not only to the development and application of environmental management instruments, but especially to the environmentally sustainable production; strengthening institutions that lead the change; development of scientific-technological base and infrastructure of social support for change.

In a conciliatory frame between development and environmental conservation, water becomes a central element to reconcile different aspirations through a cooperative and inclusive process for three countries that have social and environmental similarities that approximate a common ideal: conservation and territorial development of the Amazon. To sustainably use a territory, its environmental offer must be used properly. Water management is one of the central arguments in favor of an international city. In this regard, the integration process should begin by a phase that plans the use, conservation, and management of water in the area.

The geographical proximity between countries is not a sufficient reason for integration, for this to make sense it is necessary that they share a common project of political-territorial organization and geopolitical projection, industrialization, economic and political integration into the international system. The issue goes beyond simply building an infrastructure to take advantage of resource complementarities and comparative advantages between national economies and creates facilities to increase the regional flow of goods, resources, people and ideas.

One of the most interesting paradoxes is related to the fact that in a globalized economy whose productive infrastructure is composed of information flows, cities and regions are, by an increased way, becoming critical agents of development. In a globalized economy, national governments do not have enough power to act on the functional processes that structure their economies and societies, but the cities are more flexible at the time to act and adapt to changing market conditions, technology and culture. Strictly speaking, they have less power than national governments, but have a greater responsiveness to generate development projects with specific objectives to negotiate with multinationals to stimulate endogenous growth of small and micro enterprises and to create conditions to attract new sources of wealth, power and prestige (Castells 1995).

"There is no recipe that guarantees success in development. But if there are at least two true statements: development is in our future, it will not be with past ideas that we will reach; if the development is a product of the community they will not be others but their own members who build it." (Boisier 1992) 


\section{Territorial Integrated Management of the Tri-Border}

The articulated treatment of the potential available resources in the region of the tri-border constitutes the basis for formulating strategies for sustainable development. Its most concrete functional expression is oriented towards the creation of competitive enterprises and cross-border supply chains, seeking to exploit the complementarity of production structures. This generic answer must respond operationally to environmental and social profiles for each local level and scale of the border region as a part of a similar territorial typology. We seek, also, to suggest a set of basic proposals (strategic guidelines and actions) that value the potential of the resources available for the tri-border level to move towards integrated development processes. That effort involves identifying and enabling companies to install enterprises or competitive value chains: skills, abilities, technical and managerial innovations, creativity and willingness to invest. The key question is how to choose the potential of those resources which have, in each place, the best comparative advantage to turn them into competitive advantages over other investment initiatives. As a result of our research work we officially deliver to the authorities of the tri-border on April 15, 2015 a set of strategic directions.

\section{Strategic Actions}

As a result of the research work carried out, we have identified some strategic actions to be implemented to ensure they serve as substrate for the formulation and implementation of viable strategies for sustainable development:

- Energy for the processing of raw materials: It is essential that the power supply for industrial purposes is guaranteed, in order to enable transformation processes of raw material with added value in the triborder territory. This action will also make possible cross-border supply chains. However, this guarantee can only be realized through the effective articulation of each local government with the state or with the respective subregional government.

- Efficient telecommunications: It is essential that the quality of telecommunications, notably regargind telephone communications and the Internet, in order to activate trade relations and reduce transaction costs is guaranteed as well as improving the efficiency and effectiveness of processes coordination, monitoring and the control of production processes and chains of value. This action can only be realized through the effective articulation of local governments with suppliers of telephone service and data transmission-from a tri-border perspective.

- Agreements for border cooperation: It is essential that the Agreement of Related Border Cities-already approved by Peru is ratified by the government of Brazil. This instrument will facilitate the coexistence in the border areas of linked populations, because they will be also able to work, study, have medical care and go shopping in the nearby town of 
the other country on an equal footing, which will revitalize their relatioships. On the other hand, the implementation of the Agreement of the Free Movement of people, vehicles and cargo between Peru and Brazil is necessary too. It must be ratified by Brazil. In both cases it is necessary to perform actions of a political nature from local government and civil society organizations to ensure such ratification in the shortest time. Also, the implementation of a General Integration, Economic and Social Cooperation Treat for the creation of a common market between the Republic of Peru and the Republic of Bolivia is necessary. This promotes, among other issues, the efforts to establish mechanisms and projects of cooperation to facilitate trade and free movement of people, vehicles and goods between Peru and Bolivia.

Strategic Axes

As a result of the research work carried out, we have identified 5 main strategic lines of territorial tri-border development that are shown below along with the main strategies:

\section{Strageric Line 1-Economic Production}

Strategy 1: Promote the development of eco-businesses and sustainable activities with clean technologies.

Strategy 2: Develop a competitive and sustainable tourism, promoting thematic tourism circuits in the tri-border as the route of the shiringa and chestnut and others where natural elements are appreciated.

Strategy 3: Develop cross-border supply chains of wood and chestnut, shiringa in special areas of production.

Strategy 4: Promote and strengthen micro and small enterprises (PYMES).

Strategy 5: Implement a system of research and technology transfer, valuing traditional knowledge.

Strategy 6: Develop fishing from the coordination between local governments, respecting the closed seasons regarding not to affect resource availability.

Strategy 7: Develop productivity from market demand and with a back focus on chain building.

\section{Stragetic Line 2-Inclusive Social Development}

Strategy 1: Promote cultural identity with respect and appreciation of indigenous knowledge considering multiculturalism and rights of indigenous peoples.

Strategy 2: Protect, enhance and promote the exercise of labor rights and access to decent work for women.

Strategy 3: Promote cultural and artistic activities that strengthen the tri-border culture.

Strategy 4: Strengthen citizen prticipation in the planning, management and budget. 


\section{Stragetic Line 3-Infrastructure and Urban Development}

Strategy 1: Develop mechanisms for tri-border cooperation in infrastructure construction and supply of integrated urban services.

Strategy 2: Identify and develop alternative energy supply sources.

Strategy 3: Improve the current state of local transport routes.

Strategy 4: Develop a public transport system with better quality.

Strategy 5: Improve the coverage and quality of basic services in the triborder.

\section{Stragetic Line 4-Education, Health and Safety}

Strategy 1: Incorporate the intercultural approach and bilingual education in schools.

Strategy 2: Develop education for work in schools.

Strategy 3: Promote integrated disease prevention programs, sports and recreation for a healthy life.

Strategy 4: Develop an integrated tri-border disaster risk prevention system.

Strategy 5: Develop an integrated tri-border public safety system.

\section{Stragetic Line 5-Institutional Strengthening}

Strategy 1: Develop of international agreements to expedite the free flow of people, goods and vehicles.

Strategy 2: Strengthen the transparency in public administration and the right of access to information

Strategy 3: Train and strengthen municipal technical staff in planning, management and budget, with tri-border vision as well as for the formulation of a competitiveness tri-border plan.

Strategy 4: Strengthen the capacity of territorial integrated resilience in the triborder.

Strategy 5: Train and strengthen the municipal technical staff in identifying, formulating and financing public investment projects within the framework of the Public Private Partnerships-PPPs.

\section{Final Considerations}

Mobilize the different resources available to transform them into competitive business ventures (public or private), involves first defining the subject of territory of a proposal (tri-border), to establish the possible scope of supply of the goods or services that could be generated. In this regard, on one hand, the sources of the inputs required by the production function or by the production chain should be identified as clearly as possible, and on the other hand, the destination of the product or service produced should be identified 
(for export and/or domestic markets, applying the criteria of national, regional and local food security).

The results obtained in the first instance should be systematically discussed between all individual or associative stakeholders (unions, municipal commonwealths, producer associations, etc.), for adjustment and social and political validation. It should be noted that a more efficient economic organization of the territory, from the desirable flows of trade and the rational use of different natural resources, is enhanced with the establishment of mechanisms to encourage public participation in the integrated process of sustainable development.

Finally, the importance of relationships and social ties already established is noted. We must create territorial tissues designed to support, encourage and strengthen social bonds, favoring the interaction between people. Such environments conduct to the balanced development of border communities with a high sense of belonging and place. This feeling translates into territorial identity and is fundamental to the sustainability of development processes. The ability to achieve social peace is based precisely on the ties established between neighboring segments along the time.

\section{References}

Alegría T (2009) Metropolis Transfronteriza. Revisión de la hipótesis y evidencias de Tijuana [Tran frontier metropolis. Review of the hypotheses and evidence of Tijuana, Mexico, and San Diego, United States]. Mexico: EURE 37(110): 163165.

Arruda RSV (2010) Fronteiras e identidades: os manchineri e os jaminawa na tríplice fronteira Brasil-Bolívia-Perú [Borders and identities: the manchineri and jaminawa in the triple border Brazil-Bolívia-Perú]. Goiás: Society and Culture 13(1): 25-37.

Boisier S (1996) Modernidad y territorio [Modernity and territory]. Santiago de Chile: ILPES.

Boisier S (1992) El difícil arte de hacer región: las regiones como actores territoriales del nuevo orden internacional (conceptos, problemas y métodos) [The difficult art of doing region: regions as territorial actors of the new international order (concepts, problems and methods)]. Cuzco: Centro de Estudio Regionales Andinos Bartolomé de las Casas [Andean Regional Studies Center Bartolomé de las Casas].

Castells M (1995) La ciudad informacional. Tecnologías de la información, reestructuración económica y el proceso urbano-regional [The informational city. Information technology, economic re-structuring and the urban-regional process]. Madrid, Spain: Alianza Editorial.

Chiarella Quinhoes R (2014) Planeamiento y gestión territorial. Análisis de las dinámicas territoriales en la trifrontera entre Perú Brasil y Bolivia [Planning and territorial management. Analysis of territorial dynamics in the tri-border between Brazil, Bolivia and Peru]. Anais do I Congresso Brasileiro de Geografia Política, Geopolítica e Gestão. Rio de Janeiro: REBRAGEO: 985-998. 
Chiarella Quinhoes R (2011) Redes y territorio: la iniciativa IIRSA en foco [Networks and territory: the IIRSA initiative in focus]. Revista Espacio y Desarrollo [Space and Development Magazine]. Lima: CIGA/PUCP 23: 5-29.

Chiarella Quinhoes R (2010) Planificación del desarrollo territorial. Algunas precisiones. [Territorial development planning. Some precisions]. Revista Espacio y Desarrollo [Space and Development Magazine]. Lima: CIGA/PUCP. 22: 77-102.

Chiarella Quinhoes R (2005) Conurbación o ciudad internacional? Gestión urbana e impactos en el territorio. Iñapari-Assis Brasil-Bolpebra [Conurbation or international city? Urban management and impacts in the territory. Asis IñapariAssis Brasil-Bolpebra]. Revista Espacio y Desarrollo [Space and Development Magazine]. Lima: CIGA/PUCP 17: 69-88.

Claval P (1979) La nueva geografía [The new geography]. Barcelona, Spain: OIKOSTAU.

Conato D (2009) Fronteras de tierra y de mar: de áreas conflictivas a espacios de colaboración e integración centroamericana [Border land and sea: from areas of conflict to areas of collaboration and Central American integration]. Roma, Italy: CeSPI 103-138.

Machado LO, Riberio LP, do Rego Monteiro L (2013) Geopolítica fragmentada: interaçõestransfronteiriças entre o Acre (BR), o Peru e a Bolívia [Fragmented geopolitics: cross-border interactions between Acre (BR), Peru and Bolivia]. Cuadernos de Geografía. Revista Colombiana de Geografía-Bogotá [Notebooks of Geography. Colombian Geography Magazine-Bogota] 23(2): 15-30.

Manchineri A, Morais M (2011) Povo manchineri: Mobilidade territorial e cultura [Manchineri People: Territorial Mobility and Culture]. Revista Geográfica De América Centra [Central America Geographic Magazine] 2(47).

Simoes M (2009) Historia e memoria das tres fronteiras: Brasil, Perú e Bolívia [History and memory of the three borders: Brazil, Peru and Bolivia]. Sao Paulo: EDUC/PUC/SP: 278.

Sohn C (2010) El papel ambivalente de las fronteras en la construcción de las metrópolis transfronterizas en Europa. Los casos de Basilea, Ginebra y Luxemburgo [The ambivalent role of borders in the construction of cross-border metropolis in Europe. Cases of Basel, Geneva and Luxembourg]. Geographical Analysis Documents 56(1): 167-184.

Valero M (1998) El suroeste de Venezuela: espacios de integración fronteriza [Southwestern Venezuela: border integration spaces]. Anales de Geografía de la Universidad Complutense [Annals of Geography at the Complutense University] 18: 139-158. 